\title{
PERAN PENGAWAS KEPATUHAN DI BANK SYARIAH MANDIRI
}

\author{
Deddy Rahmat Santoso \\ Iwan Triyowono \\ Unti Ludigdo
}

Pascasarjana Fakultas Ekonomi dan Bisnis Universitas Brawijaya Malang
Jl. Mayjen Haryono 165 Malang; Telp 082143090784
Email: deddysantoso84@gmail.com

Abstract

This research try to capture a case that showing the "PengawasKepatuhan" (PKP) character in commercial debt on Bank SyariahMandiri (BSM) and also showing the conventional characteristics. This research is a kind of qualitative research that using case study method. This is also trying to capture the compliance division duties and all kind of action in commercial debt in BSM. The summery try to showing some of PKP's characteristics when they guide in compliance function. Some of characteristics define in some phase as : dealing phase, analyze phase, and debt withdrawal phase. The summery have captured some characteristics as general character on regulation, ex-ante agent character, auditor character and reporter character. In this characteristics, the conventional actions showing on some facts about the apathy attitude, the entertain action and also fraud action which direct some attitude on disobey actions in BSM. Disobey actions become a challenge in real characteristic of $P K P$ which is the preventive ideology should be strive between the regulation idealism and also the sharia principal.

Keywords: case study, PKP characteristic,convensional action, commercial debt, sharia bank. 
Abstrak

Penelitian ini berupaya memotret sebuah kasus yang dapatmenjabarkan peran Pengawas Kepatuhan (PKP) dalam pembiayaan komersial diBank Syariah Mandiri (BSM) dan mengungkap adanya sikap-sikap konvensional yang menyertai peran divisi kepatuhan tersebut. Jenis penelitian ini adalah penelitiankualitatif dengan pendekatan studikasus.Penelitianini memotret peran divisi kepatuhan dan sikapsikap yang hadir dalam pembiayaan komersialdiBSM dan menganalisis penyebab hadirnya sikap-sikap konvensional. Hasil penelitian ini juga mengungkapkan beberapa peran yang dilakukanoleh PKP dalam melakukan fungsi kepatuhan pembiayaan komersial. Beberapa peran ini dapat diuraikan dalam beberapa tahapan antara lain adalah tahapan persetujuan, tahapan analisa dan tahapan pencairan pembiayaan. Berdasarkan studikasus yang dilakukan, diperoleh beberapa potret peran PKP dalam proses pembiayaan komersial antara lain sebagai peran umum dalam regulasi, peran ex-ante agent, peran auditor dan peran reportase. Dari beberapa peran tersebut sikap konvensional ditunjukkan dalam beberapa fakta terkait sikap ketidakpedulian, semangat untuk melakukan entertain dan timbulnya tindakan fraud yang mengarahkan pada perilaku tidak patuh seorang karyawan di BSM. Hadirnya sikap menyimpang tersebut dalam peran riil PKP pada akhirnya menjadi sebuah tantangan tersendiri di mana semangat preventif harus ditegakkan diantara idealism kepatuhan terhadap regulasi dan prinsip syari'ah yang berlaku umum di lingkungan sistem perbankan.

Kata kunci: studi kasus, peran PKP, sikap-sikap konvensional, pembiayaan komersial, Bank syari' ah

\section{PENDAHULUAN}

Perusahaan perbankan sebagai organisasi pada umumnya memiliki tujuan tertentu yang ingin dicapai dalam usaha untuk memenuhi kepentingan para anggotanya. Keberhasilan dalam mencapai tujuan perusahaan merupakan prestasi atas kinerja manajemen. Simanjuntak (2005:1) berpendapat bahwa kinerja adalah tingkat pencapaian hasil atas pelaksanaan tugas tertentu. . Kinerja manajemen adalah keseluruhan kegiatan yang dilakukan manajemen untuk meningkatkan kinerja perusahaan atau organisasi, termasuk kinerja masing-masing individu dan kelompok kerja di perusahaan tersebut.

Kehadiran risiko dan pengukuran kinerja mengharuskan manajemen berinteraksi dengan lingkungan intern maupun ekstern melalui informasi. Informasi tersebut lebih lanjut dituangkan atau dirangkum dalam laporan atas kinerja perusahaan. Kinerja menjadi ukuran seberapa efisien dan efektif suatuperusahaanatau seorang manajer untuk mencapai tujuan yang memadai (Stoner, et al., 1996:9), yaitudengan kemampuan untuk meminimalkan penggunaan sumber daya dalam mencapai tujuan perusahaan secara tepat. 
Bank merupakan lembaga keuangan yang mempunyai peranan yang sangat strategisdalam menjaga stabilitas perekonomian nasional. Kegiatan utama perusahaan perbankan adalah melaksanakan fungsi perantara (intermediary) bagi pihakpihak yang berkelebihan dana (surplus of funds) dan pihak-pihakyang memerlukan dana (lack of funds)(Karim, 2001:78). Sejak diberlakukannya Undang-Undang No 10 tahun 1998 tentang Perubahan atasUndang-undang No 7 Tahun 1992 tentang Perbankan, di Indonesia diberlakukan sistem perbankan ganda (Dual Banking System) yakni sistem perbankan konvensional yang berbasis bunga dan sistem perbankan bagi hasil yang berbasis pada prinsip syari' ah Islam (yang disebut Bank Syari' ah).

Bank syariah memiliki produk yang variatif dan tentunya lebih memberikan nilai-nilai kemanusiaan yang sesuai dengan nilai-nilai syariah. Bentuk utama produk tersebut utamanya menggunakan pola bagi hasil. Namun demikian, selain pola tersebut bank syariah juga mempunyai produk-produk pendanaan dan pembiayaan dengan pola non bagi hasil. Produk-produk tersebut antara lain adalah berupa tabungan (wadiah), pengkongsian (musyarakah), sewa guna usaha (ijarah), penyertaan modal/pembiayaan (mudharabah) (Muhamad, 2002). Di dalam perbankan syari'ah pengaktualisasian nilai epistemologi berpasangan dan metafora amanah ini dapat kita lihat dari keberadaan fungsi kepatuhan dalam mengemban tugasnya. Peran dan fungsi kepatuhan yang dilaksanakan oleh seluruh jajaran bank syari' ah serta diawasi oleh pengawas kepatuhan, dapat dijadikan tolok ukur atas keberhasilan kinerja perbankan syari' ah. Kepatuhan sebagai ciri maskulinitas dalam bank syari' ah dituangkan dalam piagam kepatuhan (compliance charter) sebagaimana diatur dalam Peraturan Bank Indonesia (PBI) No. 13/2/PBI/2011.

Budaya kepatuhan dewasa ini identik dengan adanya upaya mematuhi sistem pengendalian internal. Hall (2001) menjelaskan bahwa pengendalian internal merupakan suatu sistem yang meliputi struktur organisasi beserta semua mekanisme dan ukuran-ukuran yang dipatuhi bersama untuk menjaga seluruh harta kekayaan organisasi dari berbagai arah. Sudut pandang ini mencakup rencana organisasi dan semua metode serta tindakan yang telah digunakan dalam perusahaan untuk mengamankan asetnya, mengecek kecermatan dan keandalan data akuntansi, memajukan efisiensi operasi dan mendorong ketaatan dari kebijakan yang telah ditetapkan.

Dalam penelitian ini kinerja dari Pengawas Kepatuhan (PKP) di PT. Bank Syariah Mandiri menjadi tolok ukur atas keberhasilan penerapan budaya kepatuhan pada bank syari'ah. Sisi komersial yang mampu memberikan sumbangan pendapatan tertinggi nampaknya menjadi sebuah pola yang bias dari aspek syariah. Dengan demikian tercapainya budaya kepatuhan pada bank syari'ah yang diamanahkan dalam piagam kepatuhan mampu menjadi gambaran keberhasilan manajemen bank dalam melakukan pengamanan asset serta peningkatan derajat kepatuhan pada aturan yang ada. 


\section{METODE PENELITIAN}

Penelitian ini merupakan penelitian kualitatif deskriptif dimana dalam penelitian ini peneliti dapat mengontrol dirinya sendiri dalam menganalisis situasi yang sedang dikaji. Kemudian dituangkan ke dalam bentuk tulisan berdasarkan realita dan data yang ada di lapangan. Dengan menggunakan pendekatan kualitatif diharapkan peneliti dapat menyajikan gambaran maupun hasil analisa yang pada umumnya lebih fleksibel. Metode penelitian deskriptif adalah suatu metode yang digunakan untuk menemukan pengetahuan terhadap subyek penelitian pada suatu saat tertentu (Mukhtar, 2013:10). Kata deskriptif berasal dari bahasa latin "descriptivus" yang berarti uraian. Penelitian jenis ini dimaksudkan untuk mengumpulkan informasi mengenai subyek penelitian dan perilaku subyek penelitian pada suatu periode tertentu. Penelitian deskriptif kualitatif berusaha mendeskripsikan seluruh gejala atau keadaan yang ada, yaitu keadaan gejala menurut apa adanya pada saat penelitian dilakukan.

Sukmadinata (2006:72) menjelaskan penelitian deskriptif adalah suatu bentuk penelitian yang ditujukan untuk mendeskripsikan fenomena-fenomena yang ada, baik fenomena alamiah maupun fenomena buatan manusia. Fenomena yang diamati dapat berupa bentuk, aktivitas, karakteristik, perubahan, kesamaan dan perbedaan antara fenomena satu dengan fenomena lainnya. Menurut Widodo dan Mukhtar (2000) penelitian jenis ini tidak dimaksudkan untuk menguji hipotesis tertentu, melainkan lebih dari menggambarkan apa adanya suatu gejala, variabel atau keadaan.

Pendekatan penelitian yang digunakan dalam penelitian ini adalah pendekatan studi kasus (case study research). Penelitian studi kasus merupakan sebuah metode kualitatif dimana investigator mengeksplorasi sebuah kasus atau beberapa kasus yang telah terjadi dalam sistem. Penelitian ini lebih mengedepankan adanya details dimana data yang dikumpulkan merupakan jenis data yang diperoleh dari observasi, wawancara, bukti audiovisual, dokumentasi dan laporan (Yin, 2003). Sebagai suatu upaya penelitian, studi kasus dapat memberikan nilai tambah pada pengetahuan kita secara unik tentang fenomena, individual, organisasi, sosial dan politik. Metode ini memungkinkan peneliti untuk mempertahankan karakteristik holistik dan memberikan makna dari peristiwa-peristiwa kehidupan nyata seperti siklus kehidupan seseorang, proses-proses organisasional dan manajerial, perubahan lingkungan sosial, hubungan-hubungan internasional dan kematangan industri-industri.

Jenis penelitian kualitatif studi kasus ini dibatasi oleh ukuran sebuah kasus seperti apakah sebuah kasus itu terjadi pada seorang individu, beberapa individu, sebuah kelompok, sebuah program atau pada sebuah aktivitas. Selain itu penelitian ini juga dibatasi dengan pemilihan cara untuk menganalisa kasus. Setidaknya ada tiga cara yang dapat digunakan untuk melakukan analisa, Creswell (2007) menyebutkan 3 variasi cara tersebut antara lain: single instrument case study, collective atau multiple case study, dan intrinsic case study. Variasi tersebut sesuai dengan Tabel 1. Tipe Studi Kasus berikut ini: 


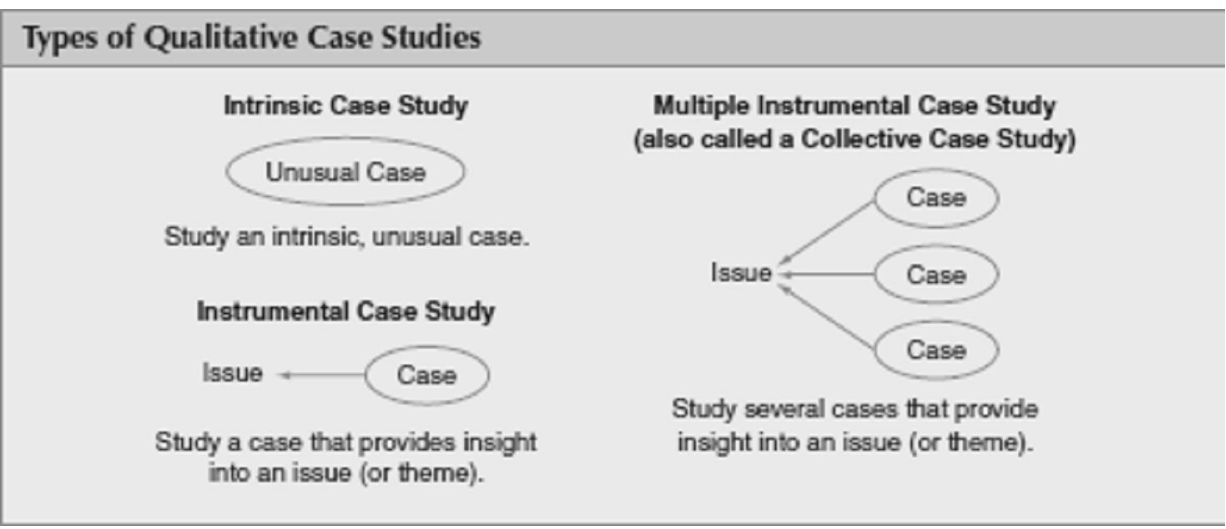

Sumber: Creswell (2007, 466)

Dari penjelasan diatas dapat disimpulkan bahwa pendekatan studi kasus (case study)memusatkan perhatian pada pengalaman subyektif. Dalam penelitian ini, penelitimenggunakan pendekatan studi kasus (case study) yaitu dengan mencoba memahami pandangan pribadi mengenai gesekan-gesekan moral dan sikap moral seorang Pengawas Kepatuhan (PKP) di PT. Bank Syariah Mandiri (BSM) dalam hal melakukan pengawalan pembiayaan komersial. Sumber informasi dalam penelitian ini adalah rekan beberapa PKP yang tersebar di beberapa cabang, marketing dan kepala unit kerja yang terkait pembiayaan komersial. Pembiayaan dalam jenis komersial dianggap peneliti memiliki kemungkinan gesekan moral yang tinggi sekaligus risiko yang beragam karena sifat pembiayaan ini adalah produktif yaitu yang umumnya menyentuh sektor kebutuhan modal kerja pada suatu usaha. Pendekatan ini sekaligus akan digunakan untuk merekam sikap-sikap moral yang hadir baik berdampak langsung maupun tidak langsung pada Pengawas Kepatuhan (PKP) dalam lingkup pembiayaan komersial.

\section{Peran Umum PKP dalam Regulasi}

Budaya Kepatuhan adalah nilai, perilaku, dan tindakan yang mendukung terciptanya kepatuhan terhadap ketentuan Bank Indonesia dan peraturan perundangundangan yang berlaku, termasuk Prinsip Syariah bagi Bank Umum Syariah dan Unit Usaha Syariah. Fungsi Kepatuhan adalah serangkaian tindakan atau langkahlangkah yang bersifat ex-ante (preventif) untuk memastikan bahwa kebijakan, ketentuan, sistem, dan prosedur, serta kegiatan usaha yang dilakukan olehBank telah sesuai dengan ketentuan Bank Indonesia dan peraturanperundang-undangan yang berlaku, termasuk Prinsip Syariah bagi BankUmum Syariah dan Unit Usaha Syariah, serta memastikan kepatuhan Bankterhadap komitmen yang dibuat oleh Bank kepada Bank Indonesia dan/atauotoritas pengawas lain yang berwenang. Dalam budaya kepatuhan juga terdapat suatu risiko yang timbul akibat Bank tidak 
mematuhidan/atau tidak melaksanakan peraturan perundang-undangan dan ketentuan yang berlaku, termasuk Prinsip Syariah bagi Bank Umum Syariah dan UnitUsaha Syariah.

Bank syariah wajib memiliki Piagam Kepatuhan seperti yang diatur dalam Peraturan Bank Indonesia (PBI) No. 13/2/PBI/2011. Piagam Kepatuhan adalah dokumen kepatuhan PT. Bank Syariah Mandiri yang dibuat untuk menjadi acuan bagi Unit Kerja dalam penerapan Budaya Kepatuhan dan Fungsi Kepatuhan. Sehubungan dengan hal tersebut, PT. Bank Syariah Mandiri menerbitkan Surat Keputusan Bersama Dewan Komisaris dan Direksi tentang Piagam Kepatuhan PT. Bank Syariah Mandiri No. 13/003-SKB/KOM.DIR yang berlaku sejak tanggal 01 September 2011.

Hendra (PKP Cabang Surabaya) menjelaskan pentingnya piagam kepatuhan dan budaya patuh sebagai berikut:

"Piagam Kepatuhan itu jadi pegangan kita yang utama dalam hal melakukan aksi-aksi yang berhubungan dengan kepatuhan. Budaya patuh yang dimaksudkan untuk menjaga perilaku karyawan agar sesuai dengan SOP yaa harus kita sikapi apa adanya terkait SOP itu sendiri. Artinya jangan sampe kita berdasarkan kebiasaan dan melalaikan SOP. Kalau patuh sama SOP kan artinya kita patuh sama kebijakan, sejatinya kebijakan itu tentu sudah sesuai sama undang-undang dan aturan yang lebih tinggi. Ini landasan kita bekerja supaya bebas sekaligus terarah."

Piagam Kepatuhan lebih jauh merupakan dokumen yang bersifat strategis dan berisi panduan, kaidah dan kebijakan Bank mengenai fungsi kepatuhan yang wajib dipatuhi oleh jajaran Bank. Maksud dari Piagam Kepatuhan adalah untuk memberikan acuan strategis bagi Bank dalam melaksanakan fungsi kepatuhan serta menerapkan kepatuhan atas ketentuan yang berlaku bagi industri perbankan. Tujuan Piagam kepatuhan adalah untuk mewujudkan budaya kepatuhan di seluruh tingkatan organisasi dan kegiatan usaha Bank serta meningkatkan pelaksanaan fungsi kepatuhan Bank sehingga bank dapat meminimalkan risiko kepatuhan. Piagam kepatuhan harus diterapkan secara maksimal sehingga efektif dalam mewujudkan budaya kepatuhan seluruh jajaran perbankan syariah.

Perwujudan budaya kepatuhan merupakan tanggung jawab seluruh jajaran Bank, sehingga Bank berkewajiban menyusun langkah-langkah dalam rangka mendukung terciptanya budaya kepatuhan antara lain pembuatan sistem, program, kerangka pikir, compliance charter, kode etik kepatuhan dan kebijakan kepatuhan. Penerapan kepatuhan Bank atas ketentuan dan komitmen yang berlaku harus menjadi fungsi kepatuhan yang implementatif. Oleh karena itu, Bank berkewajiban menetapkan serangkaian tindakan atau langkah-langkah yang bersifat ex-ante (preventif) untuk memastikan bahwa ketentuan internal Bank telah sesuai (tidak melanggar) ketentuan eksternal. Penerapan fungsi kepatuhan pada seluruh kegiatan 
usaha Bank dan jenjang organisasi harus berjalan melalui penetapan Direktur yang membawahi fungsi kepatuhan dan pembentukan satuan kerja kepatuhan serta kepatuhan melekat pada unit-unit kerja Bank. Terkait adanya fungsi kepatuhan yang implementatif, Uya (PKP Cabang Medan) menjelaskan:

"Implementatif atau tidaknya fungsi kepatuhan itu harus terukur. Oleh sebab itu kerjaan kita itu juga harus kita evaluasi dan kita laporkan ke atasan kita. Bisa jadi akan ada perbaikan cara kerja terkait hal-hal kepatuhan. Transformasi itu bisa kita rasakan dari perubahan Kertas Kerja Pemeriksaan (KKP) yang dulunya harus berlembar-lembar hingga saat ini hanya pakai satu lembar checklist saja sudah bisa dipahami."(scan KKP dilampirkan)

Pembentukan karakter fungsi kepatuhan yang implementif diyakini dapat dilakukan dari adanya evaluasi cara kerja. Dari cara kerja PKP misalnya sebuah proses evaluasi dapat memberikan sumbangan positif dalam pembentukan cara kerja yang lebih simpel yaitu dengan adanya perbaikan atas Kertas Kerja Pemeriksaan (KKP). Dalam kinerjanya PKP menggunakan KKP untuk mempermudah dalam mencari gambaran atas review yang dilakukan. Gambaran atau hasil review inilah yang kemudian lebih menggambarkan tingkat kepatuhan sebuah fungsi di BSM.

\section{Pelemahan Peran Preventif (Ex-Ante) PKP dalam Tugas}

Abu Hurairah r.a. berkata, Rasulullah saw. bersabda, ”Tunaikanlah amanat kepada orang yang memberikan amanat itu kepadamu, dan janganlah kamu berkhianat kepada orang yang menghianatimu." (HR. Abu Dawud, at-Tirmidzi dan Al Hakim)

Selama beberapa dasawarsa, praktik ekonomi dan organisasi telah dikembangkan dengan berbagai arah kebudayaan. Pengembangan ini tentunya tidak lepas dari adanya asa ataupun selera pribadi yang dilakukan berdasarkan tuntutan nafsu semata (homo economicus), tanpa sikap kepedulian apakah hal tersebut bertentangan dengan norma agama ataukah tidak. Dalam kaidah ini (sebut saja kaidah ekonomi konvensional), manusia dianggap sebagai individu yang rasional (rational man) yang mampu membuat keputusan terbaik bagi dirinya berdasarkan preferensinya sendiri (self interest). Logika ini yang menuntut setiap individu homo economicus hanya berorientasi kepada pencarian keuntungan terbesar bagi dirinya dengan pengorbanan yang seminimal mungkin.

Sebagai sebuah dasar logika ataupun motivasi, tentunya hal demikian tidak terlepas dari kehidupan dan dinamika perbankan. PT. Bank Syariah Mandiri sebagai lembaga perbankan syariahpun tidak serta merta terhindar dari proses tarik-menarik situasi dan gaya-gaya konvensional yang terlanjur kental. Mulai dari setting-an permintaan calon nasabah yang tulus dengan kebutuhan perbankannya, hingga 
motivasi untuk terus menguntungkan pribadinya dengan atau tanpa campur tangan pihak internal perbankan itu sendiri. Dalam kondisi ini sebuah organisasi perbankan syariah memerlukan infrastruktur yang baik sehingga mampu memilah dan memilih serta mendeteksi beragam kepentingan sehingga tidak berbelok dari semangat kesyariah-an itu sendiri.

Namun demikian, sebagai sebuah fungsi tentunya PKP tidak terlepas dari beberapa distorsi fungsi. PKP sebagai sebuah jabatan yang melakukan pengawalan harus mampu secara konsisten mengarahkan setiap tindakan marketing ataupun perangkat unit kerja dalam setiap aktivitas perbankan. Disamping itu seorang PKP bisa jadi juga dituntut untuk memberikan fleksibilitas ketika sebuah risiko muncul atas kesalahan yang dilakukan ataupun risiko itu muncul sebagai risiko bawaan. Keputusan untuk tegas atau fleksibel, sudah pasti membuat PKP seringkali akan terjebak dalam tindakan yang disorientasi.

Semangat untuk melakukan pengawalan ini tidak terlepas dari firman Allah berikut:

”....Dan tolong-menolonglah kamu dalam (mengerjakan) kebajikan dan takwa, dan jangan tolong-menolong dalam berbuat dosa dan pelanggaran. Dan bertakwalah kamu kepada Allah, sesungguhnya Allah amat berat siksa-Nya.” (QS. Al-Maa'idah: 2)

Semangat PKP dalam melakukan pengawalan tentunya secara religius harus mampu dipertahankan dengan semangat amar ma'ruf nahi munkar. Yaitu dengan merealisasikan setiap nilai-nilai kebaikan dan menentang nilai-nilai keburukan. Bagi PKP hal ini tidak mudah untuk dilakukan. Kepentingan manajemen yang ingin meraih laba maksimal, seringkali membutakan aspek prudensialitas dan pengukuran risiko yang dapat dipertanggunjawabkan. Kondisi tersebut menjadi perhatian Nevi (PKP Cabang Solo) yang diungkapkan dari uraian berikut:

"Seringkali heran kalau melihat perilaku mereka (Kepala Cabang dan Marketing). Bukankah kita ini sama-sama tahu kalau identitas dan dokumen legalitas usaha itu menunjang analisa dasar. Tapi masih aja lewat! Ada lagi rekening koran dipalsu, di mark up, truss gimana analisa bisa valid?"

Sebut saja dalam aktivitas akan dilakukan pencairan pembiayaan, seringkali marketing atau unit kerja melakukan aktivitas analisa yang tidak sempurna. Mulai dari pengumpulan dokumentasi identitas hingga dokumentasi legalitas yang tidak lengkap, perhitungan analisa rekening yang telah di mark-up jauh dari angka realistisnya sampai dengan eksistensi nasabah yang diragukan usaha dan keberadaannya. Kondisi demikian menuntut seorang PKP tidak hanya berhati-hati dalam melakukan pengawalan, namun sikap waspada dan skeptis senantiasa harus dikembangkan dalam setiap keadaan. 
Kondisi lain yang harus dicermati adalah adanya peraturan sebagai dasar aktivitas berorganisasi yang memiliki banyak celah yang dapat dimanfaatkan secara positif sekaligus negatif. Hal ini terjadi karena adanya persepsi yang beragam terhadap penafsiran aturan-aturan tersebut. Kehendak diri (self) dalam situasi ini memegang peranan penting. Chaplin $(1981,358)$ mengartikan persepsi dengan beberapa definisi berikut:

1. Proses mengetahui atau mengenali objek dan kejadian dengan bantuan indera.

2. Kesadaran dari proses-proses organis.

3. Satu kelompok penginderaan dengan penambahan arti-arti yang berasal dari pengalaman di masa lalu.

Dalam arti lain persepsi diartikan sebagai proses dimana seorang menjadi sadar akan segala sesuatu dalam lingkungannya melalui indera-indera yang dimilikinya, pengetahuan lingkungan yang diperoleh melalui intepretasi data indera atau menafsirkan stimulus yang telah ada di otak (Adz-Dzakiey, 2010). Dalam hal pekerjaan, Hafidz (PKP Cabang Gresik) menegaskan efek dari sebuah persepsi sebagai berikut:

"Kalau mikirnya target terus, syar'i nya ilang. Kalau mikirnya syar'i, targetnya gak tercapai."

Persepsi memiliki fungsi yang sangat penting dalam kehidupan, yang dengannya seorang individu dapat memahami apa yang bermanfaat dan apa yang tidak (konsep utilitarianisme). Pembahasan tentang manfaat ini pun akan melebar seiring dengan keinginan, keserakahan dan motivasi tiap individu. Misalnya saja dalam aktivitas perbankan, seorang marketing dapat menerima nasabah dengan kualitas apapun ketika harus dihadapkan dengan pemenuhan target dana atau target pembiayaan. Hal ini tentu memberikan konsekuensi yang berbeda. Jika nasabah yang diproses adalah nasabah yang "baik" maka aktivitas jasa dan manfaat jasa yang diberikan marketing tidak akan memberikan risiko yang merugikan bagi marketing dan bank tersebut, demikian sebaliknya akan terjadi.

Dalam logika mazhab mainstream beberapa permasalahan ekonomi muncul karena sumber daya yang terbatas yang dihadapkan pada keinginan manusia yang tidak terbatas (Al-Arif, 2011). Persepsi yang sarat akan faktor materi akan menghantarkan seorang individu hanya pada kepentingan dirinya sendiri. Termasuk dalam hal penyelesaian masalah keterbatasan sumber daya, dalam tataran konvensional akan menuntut setiap pribadinya untuk melakukan pilihan tanpa memperdulikan apakah itu bertentangan dengan norma serta nilai agama atau tidak. Sedangkan dalam ekonomi Islam, penentuan pilihan tidak bisa seenaknya saja, sebab semua sendi kehidupan kita telah diatur Al-Qur'an dan Sunnah.

Dalam tataran ini tentu seorang bankir syari' ah dituntut untuk menggunakan berbagai instrumen persepsi yang dimiliki sehingga mampu mencapai suatu pengetahuan, wawasan dan wacana yang meyakinkan dalam beragam persoalan. 
Menurut Adz Dzakiey $(2010,304)$ tiga instrumen tersebut antara lain: qalbu (hati), inderawi dan akal pikiran. Sepaham dengan hal tersebut Safrizal (Kepala Cabang) menjelaskan sebagai berikut:

"Baik marketing maupun semua organ harus sadar diri dan pake hati. Minimal kalau tahu benar/salah, kita ndak melulu ngomong pencapaian target, gak melulu menghalalkan segala cara. Malulah kita ini perusahaan syariah, perilakunya yaa harus disesuaikan. Sebisa mungkin sikap dan sifat Nabi itu kita tiru."

Dengan menggunakan qalbu (hati) seorang individu akan mampu merasakan keimanan dan ketakwaan, keyakinan dan kemantapan tauhid, serta kedekatannya dengan Sang Maha Pencipta. Dalam realitas tauhid, seorang bankir akan senantiasa dihadapkan pada analisa tentang apa yang baik dan buruk atau tentang apa yang haqq dan yang batil. Sebut saja ketika seorang calon nasabah menawarkan sejumlah persentase kepada marketing ataupun PKP jika dana pinjaman dicairkan. Realitas tauhid dengan menggunakan qalbu tentu akan melakukan pertentangan dimana unsur materi akan menjadi prioritas yang minor, sebaliknya unsur ukhrawi akan menjadi prioritas mayor.

\section{PKP dalam Melaksanakan Audit dan Deteksi Fraud Triangle}

Tekanan dalam pekerjaan dan kehidupan sering kali mengarahkan seseorang untuk melakukan tindakan menyimpang. Beberapa jenis tekanan akan mengarahkan seseorang untuk menghasilkan penghasilan tambahan dengan cara yang terlarang, yaitu dengan melakukan pencurian ataupun pemanfaatan kelemahan sistem. Fraud biasanya berawal dari tindakan yang kecil yang secara berkelanjutan menjadi sebuah kebiasaan atau kelemahan dari sebuah sistem.

Cendrowski $(2007,42)$ menjelaskan setidaknya ada 3 motif dari pelaku fraud yang harus diperhatikan yaitu adanya kebutuhan gaya hidup (lifestyle); adanya aktivitas terlarang seperti judi dan obat terlarang; dan adanya tekanan hidup. Seringkali dalam keseharian dapat kita lihat bahwa seseorang melakukan tindakan konsumtif yang berlebihan. Tindakan ini dapat kita lihat dari perilaku atau pilihan gaya hidup seperti kebiasaan makan di restoran mahal, pembelian baju, jam tangan dan perhiasan yang mahal. Indikasi lain juga dapat ditengarai dari kepemilikan kendaraan dan rumah. Dalam lingkup perbankan indikasi-indikasi ini semakin nyata kita rasakan. Pentingnya mengamati adanya indikasi diungkapkan oleh Safrizal (Kepala Cabang) sebagai berikut:

"Kurang dari satu tahun Fahmi (Marketing) sudah bisa beli 2 mobil dan rumah di lingkungan yang elit. Udah gitu kebiasaan dia traktir orang di resto yang mahal." 
Sikap skeptis dalam hal ini tentu harus dikembangkan dengan melakukan upaya investigatif. Sehingga dalam melakukan tindakan terkait mitigasi risiko dapat dipertanggungjawabkan didepan hukum. Dalam upayanya mewujudkan budaya patuh, PKP sering kali mendapati informasi yang sifatnya sepele. Sebut saja tentang informasi kebiasaan marketing yang suka mentraktir. Upaya investigatif haruslah bersifat menyeluruh terkait apakah ada kaitannya dengan pencairan pembiayaan nasabah atau tidak; apakah ada laporan dari nasabah; atau apakah telah dilakukan konfirmasi kepada nasabah terkait pemberian sejumlah dana setelah pencairan pembiayaan.

Seringkali seseorang membutuhkan adanya "extra funds" karena menganggap bahwa biaya hidupnya lebih tinggi dari pendapatan yang diraihnya tiap bulan. Adanya kebutuhan terkait pengobatan, kebutuhan rumah tangga, penggunaan kartu kredit yang tak terkontrol dan meningkatnya biaya hidup, seringkali mempengaruhi seseorang untuk melakukan tindakan menyimpang. Tindakan semacam ini semakin ironis karena pada umumnya dilakukan oleh orang yang dipercaya oleh manajemen, sebut saja marketing atau kepala unit kerja dengan beberapa akses dan kemudahan yang diberikan.

Rasionalisasi adalah satu-satunya alasan mengapa seorang bankir dapat berperilaku menyimpang. Hal ini dapat dicitrakan dari pernyataan Yuarfi (Marketing) dalam proses investigasi berikut ini:

"Kita ini mesinnya! Mau dikasi sampah, mau enggak terserah kita!"

Pemberian amanah dan tanggung jawab yang bersifat eksklusif sering kali dimaknai bahwa "sayalah mesin utama perusahaan ini". Dari sudut pandang marketing komersial misalnya, sebagai sebuah organ marketing komersial tentunya memiliki prestige eksklusif dimana mereka memiliki kuasa dalam melakukan proses pembiayaan dengan limit miliyaran rupiah. Logika yang mengarah dalam sudut pandang ini adalah adanya pencairan besar, maka perusahaan akan mendapat fee base pembiayaan yang besar. Cara pandang ini tentu memiliki implikasi negatif secara berkelanjutan.

Sebagai mesin utama seringkali seorang marketing atau kepala unit kerja terlatih secara tidak sadar untuk melakukan penyimpangan aturan. Dalam satu kasus misalnya, karena dianggap paling penting seorang kepala unit kerja yang sudah percaya dengan marketingnya menginginkan pencairan pembiayaan segera dilakukan sementara itu proses analisa secara utuh belum selesai dilakukan. Kondisi ini dapat kita lihat dari ungkapan Untung (PKP Jemur Handayani) berikut:

"Pembiayaan ruko Dlanggu Trade Centre itu kan belum disurvey sama sekali. Kok MM (Marketing Manager) dan Kepala Cabang percaya aja sih! Padahal setelah kita kesana masih juga berupa tanah uruk. Lagi pula akad yang kita pake Murabahah. Ndak syar'i sama sekali!" 
Pernyataan tersebut menunjukkan beberapa kesalahan yang ditimbulkan oleh adanya rasionalisasi. Dalam sudut pandang syari'ah, kondisi pembiayaan ruko biasanya dilakukan dalam akad murabahah. Hal ini memberi konsekuensi bahwa pembiayaan ruko hanya bisa dilakukan pada saat ruko sudah berdiri. Beda halnya dengan akad istisna yang memperkenankan pembiayaan berdasar by progress. Pada umumnya indikasi semacam ini mengarah pada tindakan fraud atau menyimpang lainnya. Melalui investigasi yang mendalam dari kasus ini pada akhirnya didapati bukti bahwa marketing memanfaatkan nasabah untuk mendapatkan sejumlah dana jika pembiayaan tersebut dapat dengan cepat dicairkan, tentunya dengan nilai yang telah di mark up.

\section{PKP dalam Melaksanakan Reportase Laporan Insidentil}

Gejala atau indikasi menjadi suatu hal yang harus diwaspadai oleh bankir. Setiap organ dalam perusahaan harus berperan aktif dalam memberikan contoh gaya hidup terbaik yang terbebas dari aspek kecurangan. Adanya ketertarikan pada pilihan gaya hidup mampu memaksa seseorang untuk bertindak jauh dan merugikan perusahaan. Sebagaimana dijelaskan tentang adanya gejala fraud dalam triangle fraud, kecenderungan gaya hidup memenuhi unsur pressure/tekanan hidup. Investigasi mendalam di sebuah kasus menunjukkan pernyataan yang sulit melepaskan diri dari adanya tuntutan gaya hidup. Misalnya dari pernyataan Fahmi (Marketing) berikut:

"Honda City buat aku, Honda Jazz nya untuk istri. Kalau HP baru punya

Apple 5 sudah keluar Apple 5s, belilah biar ndak ketinggalan jaman."

Gaya hidup dengan bergelimang kemewahan dalam kasus ini dapat dilihat sebagai sebuah bius yang dapat membuai setiap orang dengan sadar maupun tidak sadar. Gaya hidup satu sisi dimaknai sebagai simbol kesejahteraan sedangkan dalam sisi yang lain merupakan simbol ketidaktertinggalan seseorang terhadap perkembangan jaman.

Fenomena triangle fraud yang mendasari tindakan menyimpang menghadirkan situasi yang harus diwaspadai oleh bankir, dan PKP pada khususnya. Sebagai struktur yang terlanjur ditakuti, terkadang posisi PKP menjadi sulit dalam melakukan pengamatan. Beberapa orang akan cenderung merasa perlu untuk menutup diri dan mencari jalan aman. Uya sebagai PKP Medan digambarkan rekan kerjanya sebagai sosok yang keras dan ditakuti. Posisi ini menyebabkan rekan kerja Uya tidak mudah mengungkap kasus atau menandai gejala pada sebuah kasus. Komentar ini sesuai dengan penuturan Irfan (PKP Medan) berikut ini:

"Bang Uya itu galaknya setengah mati, kadang orang jadi enggan cerita. Ehh larinya pada ke saya. Kadang pas ngopi bareng, kalau ada Bang Uya pada diem. Begitu orangnya pergi, baru dehh ada omongan si A begini, si B begini." 
Pendekatan dengan sikap yang baik tentunya akan mengungkapkan banyak fakta. Dalam konteks ini pendekatan dengan bersikap baik membuktikan tidak adanya keengganan dari informan untuk memberikan informasi yang memadai terhadap suatu kasus. Informasi yang berupa indikasi menjadi sebuah awal yang sangat penting bagi pengembangan sebuah kasus yaitu dengan memilah dan memilih informasi yang memiliki relevansi.

Sebagai ex-ante agent, PKP sekali lagi merupakan organ yang fungsinya melakukan mitigasi. Dalam hal penyidikan gejala ini maka PKP memiliki tools yang dapat digunakan yang disebut Laporan Insidentil. Laporan ini merupakan bentuk komprehensif sebuah proses investigasi suatu masalah. Dalam laporan ini tentunya PKP tidak hanya mengungkap gejala, melainkan dalam tataran yang lebih jauh laporan ini juga menjelaskan tentang hadirnya bukti dan efek dari sebuah permasalahan.

Laporan insidentil berperan dalam memberikan uraian permasalahan bagi pihak otoritas tertinggi di kantor pusat. Laporan insidentil menjadi bahan awal untuk dilakukannya investigasi lebih mendalam oleh Internal Audit Division (IAD). Namun dalam prosesnya, penggunaan laporan ini seringkali menghadapi hambatan. Hal ini terurai dari ungkapan Hafidz (PKP Cabang Gresik) berikut ini:

"Laporan Insidentil (lapin) itu alatnya kita untuk deteksi lebih dini. Tapi penyikapannya oleh kantor pusat seringkali lambat. Yang kita report disitu masih gejala, ditindaklanjutinya lama jadinya kasus beneran deh."

PKP seringkali menghadapi situasi yang bergam dalam uraian di atas. Hal ini tentu menjadikan fungsi PKP sebagai organ yang diharapkan dapat melakukan deteksi dini menjadi lemah. Tidak hanya itu, adanya pelaporan yang tidak kunjung ditindaklanjuti oleh kantor pusat menjadikan kinerja PKP tidak mampu memenuhi target yang diharapkan manajemen. Kondisi ini memunculkan kerugian tidak hanya dari sisi kinerja PKP yang dilemahkan, melainkan terlambatnya tindak lanjut ini diyakini memunculkan masalah yang tadinya diyakini masih bisa ditanggulangi.

\section{Analis sebagai Generalisasi Peran PKP}

Eksistensi PKP yang sering menghadapi beragam permasalahan, memunculkan peran yang berbeda dari yang telah diamanahkan dalam regulasi. Peran Ex-Ante sesuai Peraturan Bank Indonesia No. 13/2/PBI/2011 dalam praktik dilapangan tentunya membutuhkan sikap yang proaktif dan fleksibilitas yang tinggi. Hadirnya sejumlah permasalahan tidak kemudian menyurutkan aktivitas PKP dalam melakukan mitigasi permasalahan. Dalam tataran ini, tidak maksimalnya peran Ex-Ante memunculkan peran lain dalam bentuk peran Auditor, peran Reporter, dan peran Motivator. Empat peran PKP ini pada akhirnya akan mampu mencerminkan bahwa sejatinya 
generalisasi peran PKP merupakan sebuah fungsi analis yang menuntut pekerjaan yang terperinci dan terencana serta memiliki sasaran yang jelas.

Terminologi kata analis sesuai dengan Kamus Besar Bahasa Indonesia didefinisikan sebagai orang yang menganalisis atau melakukan analisis. Dalam sumber yang sama, analisis memiliki beberapa definisi yang spesifik sebagaimana diuraikan sebagai berikut:

- Analisis merupakan penyelidikan terhadap suatu peristiwa (karangan, perbuatan, dsb) untuk mengetahui keadaan yang sebenarnya (sebab-musabab, duduk perkaranya, dsb).

- Terkait ilmu manajemen maka analisis diartikan sebagai penguraian suatu pokok atas berbagai bagiannya dan penelaahan bagian itu sendiri serta hubungan antarbagian untuk memperoleh pengertian yang tepat dan pemahaman arti keseluruhan.

- Secara induktif, analisis merupakan penetapan kebenaran suatu hal atau perumusan umum mengenai suatu gejala dengan cara mempelajari kasus atas kejadian khusus yang berhubungan dengan hal itu.

- Terkait jabatan, analisis merupakan penyelidikan tentang kemampuan dan kepribadian seseorang dalam hubungan dengan pekerjaan yang menjadi tanggung jawabnya.

Peran Ex-Ante yang diamanahkan kepada PKP pada prinsipnya meliputi banyak hal. Ex-Ante atau dalam regulasi lebih dimaknai sebagai jargon preventif, memberikan ruang yang cukup luas bagi PKP untuk bertindak. Hadirnya sejumlah kasus secara empiris telah membuktikan bahwa peran seorang PKP tidak hanya dibatasi pada peran Ex Ante sebagaimana diamanahkan Peraturan Bank Indonesia No. 13/2/PBI/2011. Namun peran lain juga dapat diuraikan sesuai dengan fleksibilitas yang dibutuhkan. Peran Ex Ante dan peran lain seperti peran auditor, peran reporter dan peran motivator pada akhirnya dapat digeneralisasi sebagai peran analis. Generalisasi peran ini sesuai dengan terminologi tugas seorang analis yang meliputi penyelidikan sebab-musabab sebuah peristiwa, penyelidikan kemampuan dan kepribadian seseorang, penguraian hubungan antar bagian hingga pencarian kesimpulan atas suatu kasus. Dengan demikian sesungguhnya makna peran analis bagi jabatan PKP menunjukkan adanya fleksibilitas terhadap fungsi yang diharapkan oleh manajemen dalam peran aktifnya menjaga kepatuhan di BSM.

\section{DAFTAR PUSTAKA}

Cendrowski, M., and Petro. 2007. The Handbook of Fraud Detterence. New Jersey: John Wiley \& Sons Inc.

Creswell, J. 2007. Qualitative Research Design-Choosing Among Five Approaches. California: Sage Publication. 
Hall, A.J. 2001. SistemInformasiAkuntansi. Jakarta: Salemba Empat.

Karim, A.A. 2006. Bank Islam Analisis Fiqih dan Keuangan. Jakarta:PT. Raja Grafindo Persada.

Muhamad. 2002. Dasar-dasarKeuanganIslami. Yogyakarta: Ekonisia.

Mukhtar, W. 2000. KonstruksiKeArahPenelitianDeskriptif. Jogyakarta: Avyrouz.

Mukhtar. 2013. MetodePraktisPenelitianDeskriptifKualitatif. Jakarta: Referensi.

Simanjuntak, P.J. 2005. Manajemen dan Evaluasi Kerja. , Jakarta: Lembaga Penerbit FEUI.

Stoner, James, A.F., Freeman, R., Edward, Gilbert, J.R., Daniel, R. 1996. Manajemen, Jilid I, PT Bhuana Ilmu Populer.

Yin, Robert, K. 2003.Case Study Research: Design and Method (3rded.), Thousand Oaks, CA: Sage. 